\title{
Temperature and Precipitation Development at Svalbard 1900-2100
}

\author{
Eirik J. Førland, ${ }^{1}$ Rasmus Benestad, ${ }^{1}$ Inger Hanssen-Bauer, ${ }^{1,2}$ \\ Jan Erik Haugen, ${ }^{1}$ and Torill Engen Skaugen ${ }^{1}$
}

${ }^{1}$ Norwegian Meteorological Institute, P.O. Box 43 Blindern, 0313 Oslo, Norway

${ }^{2}$ Telemark University College, P.O. Box 203, 3901 Porsgrunn, Norway

Correspondence should be addressed to Eirik J. Førland, eirik.forland@met.no

Received 26 September 2011; Revised 6 December 2011; Accepted 20 December 2011

Academic Editor: Stefania Argentini

Copyright ( 2011 Eirik J. Førland et al. This is an open access article distributed under the Creative Commons Attribution License, which permits unrestricted use, distribution, and reproduction in any medium, provided the original work is properly cited.

\begin{abstract}
Substantial variations in temperature and precipitation have been observed since the first permanent weather station was established in the Svalbard region in 1911. Temperature and precipitation development are analysed for the longest observational series, and periods with positive and negative trends are identified. For all temperature series, positive linear trends are found for annual values as well as spring, summer, and autumn series. A very strong winter warming is identified for the latest decades. Evaluation of temperature trends downscaled from global climate models forced with observed greenhouse gas emissions suggests that the downscaled results do span the observation-based trends at Svalbard Airport 1912-2010. Novel projections focussing on the Svalbard region indicate a future warming rate up to year 2100 three times stronger than observed during the latest 100 years. The average winter temperature in the Longyearbyen area at the end of this century is projected to be around $10^{\circ} \mathrm{C}$ higher than in present climate. Also for precipitation, the long-term observational series indicate an increase and the projections indicate a further increase up to year 2100 .
\end{abstract}

\section{Introduction}

The Arctic land areas have over the last 2-3 decades experienced more warming that any other region on earth $[1,2]$. This "Arctic amplification" may be due to feedback mechanisms from loss of sea ice [3] or changes in atmospheric and oceanic circulation [4]. Similarly, Serreze et al. [5] interpret the Arctic temperature anomalies for the most recent decade 2000-2009 as reflecting the combined effects of (1) a general background warming which is part of the planet's response to positive radiative forcing, (2) anomalies in the atmospheric circulation, and (3) changes in characteristics of the surface, in particular, reduced sea ice extent and higher sea surface temperatures compared to climatology. Climate models $[1,2,6]$ furthermore indicate that anthropogenic global warming also in the future will be enhanced in the northern high latitudes by complex feedback mechanisms in the atmosphere-ocean-ice system.
The most sophisticated tools for describing future longterm climate development are the atmosphere ocean general circulation models (AOGCMs). These models include a description of physical processes associated with the atmosphere, oceans, sea ice, and often land surface processes. The resolution in the AOGCMs is presently sufficient for modelling most of the large-scale features in the atmosphere, but in general still too coarse for reproducing the climate on regional or local scale.

For most studies of impacts of climate change, detailed scenarios are needed for specific locations, that is, with a much more detailed spatial resolution than the present simulations with global climate models. To get more sitespecific climate projections for the Svalbard region, different downscaling techniques (dynamical and empiricalstatistical) were used to "downscale" results from global climate models to regional and local scales. A large variety of national and international global climate model results (incl. 
the CMIP3 ensemble [7]) were in this study downscaled for the Svalbard region and particularly for the Longyearbyen area.

In regional attribution studies for the Arctic, the importance of natural variability must be recognized. In climate model simulations, the Arctic signal resulting from humaninduced warming is large but the variability (noise) is also large. As the signal-to-noise-ratio may be lower in the Arctic than at lower latitudes [8], most of the projections in this study are focussing on the end of the 21 st century. In the Arctic, data scarcity and measuring problems are other important issues. To monitor the long-term variations of climate conditions in the Svalbard region, it is important to make optimal use of observational series from the region.

This paper describes the observed variations in temperature and precipitation during the latest 100 years (Section 2), methods and background data for applying AOGCMs to provide regional and local climate information (Section 3), projections of climate development in the Svalbard region up to year 2100 (Section 4), and examples of projected changes in daily temperatures in the Longyearbyen (Svalbard Airport) area (Section 5).

\section{Observed Climate Development at Svalbard during the Last 100 Years}

2.1. Temperature. The first permanent weather station at Svalbard was established in Green Harbour in 1911 [9]. During the last century, there have been several relocations of the different weather station in the Svalbard region (Figure 1) [10]. Because of large climate gradients and the harsh weather conditions, even small changes at Arctic measuring sites may cause substantial changes in measuring conditions. Identification of inhomogeneities in Arctic series is also complicated by the sparse station network. The present temperature measurements at Svalbard Airport and Ny-Ålesund have been performed at the same sites since 1975, but by combining several series, homogenised, composite temperature series are established for the Longyearbyen/Svalbard Airport area back to 1911 and for Ny-Ålesund back to 1934 [9-11].

Table 1 shows that the average annual temperature in the "standard normal period 1961-90" [12] range from $-2.4^{\circ} \mathrm{C}$ for Bjørnøya to $-6.7^{\circ} \mathrm{C}$ at Svalbard Airport, and with average winter temperatures of -15 to $-13^{\circ} \mathrm{C}$ for the Spitsbergen stations. Up to the most recent normal period 1981-2010 [12], Table 1 shows an increase in average annual temperatures of $1-2^{\circ} \mathrm{C}$. The average winter temperatures have increased by $3.5^{\circ} \mathrm{C}$ at both Hopen and Svalbard Airport, while the summer increases at all stations are between 0.5$1.0^{\circ} \mathrm{C}$

The time series of annual mean temperatures for the stations in the Svalbard region show a quite similar longterm pattern (Figure 2). The temperature has increased in all seasons (cf. Table 2) with the strongest increase in winter and spring. The smoothed graphs indicate that there is variability on a multidecadal scale, leading to mainly positive temperature trends before the 1930s, then a relatively warm period during the subsequent two decades, a temperature decrease from the 1950 s to the 1960s, and thereafter a general temperature increase. These features are discussed by Hanssen-Bauer [13] and are also seen for other parts of the Arctic (e.g., [14]). Although data coverage was limited in the Arctic in the first half of the 20th century, the spatial pattern of the earlier warm period in the 1930s and 1940s appears to have been different from that of the current warm anomaly. In particular, the current warm period is partly linked to the Northern Annual Mode and affects a broader region [14].

While the dynamics of the warming in Svalbard prior to the 1930s is still not fully understood, the warming from the 1960 s to the mid 1990s is clearly linked to atmospheric circulation patterns favouring increased southerly and southwesterly winds in the Svalbard area [15]. This agrees well with Rigor et al. [16] who state that more than half the warming over the eastern Arctic Ocean and the cooling over the Labrador Sea from the 1970s to the 1990s is accounted for by the Arctic Oscillation (AO), and Polyakov et al. [14] who state that the Northern Annual Mode is partly responsible for the Arctic warming in this period. The latest decade, however, show rather different patterns. While 5 of the 10 warmest winters in the Svalbard Airport composite series occurred after 2000 (2005, 2006, 2007, 2008, and 2010), several of these winters were characterised by average or even low AO mode. Recently it is suggested $[17,18]$ that the recent loss of Arctic sea ice is responsible for the high Arctic temperatures these later years, not only by directly contributing to altering the heat budget of the atmosphere in the area, but also by leading to a modification of large scale atmospheric circulation towards the "Warm ArcticCold Continents" wind pattern.

Linear trends (Table 2) were used to quantify the temperature development in Svalbard, even though there is certain scepticism against using linear trends as a measure for climate change, because such changes not necessarily occur linearly [19]. Also, linear trends for short time series are sensitive to the start and ending points. Earlier studies (e.g., [1]) have shown that the longest Arctic series by optimal choice of breaking points can be divided into three periods where the first and the last show statistically significant warming, while the middle period shows statistically significant cooling, cf. Figure 2. In order to make the trends for the stations in the Svalbard region directly comparable in different periods, the present study does not use these "optimal periods," but rather linear trends for four $\sim 23$-year periods where several stations were running simultaneously (1920-1942, 1943-1965, 19661988, and 1989-2011), Table 2.

In the first period (1920-1942), the composite Svalbard Airport series show a warming (annually and during autumn and winter). The huge warming of the Arctic in the decades before the 1940s is often called "early 20th century warming" and is one of the most spectacular climate events of the twentieth century [20]. In the next period (1943-1965), all stations tend to show negative trends in annual temperatures. The cooling was particularly strong $\left(1.5-1.8^{\circ} \mathrm{C}\right.$ per decade in the composite $\mathrm{Ny}$-Ålesund and Svalbard Airport series) during the winter season. For the last two periods (19661988 and 1989-2011), there has been a warming at all stations and during all seasons, except for a minor cooling at 


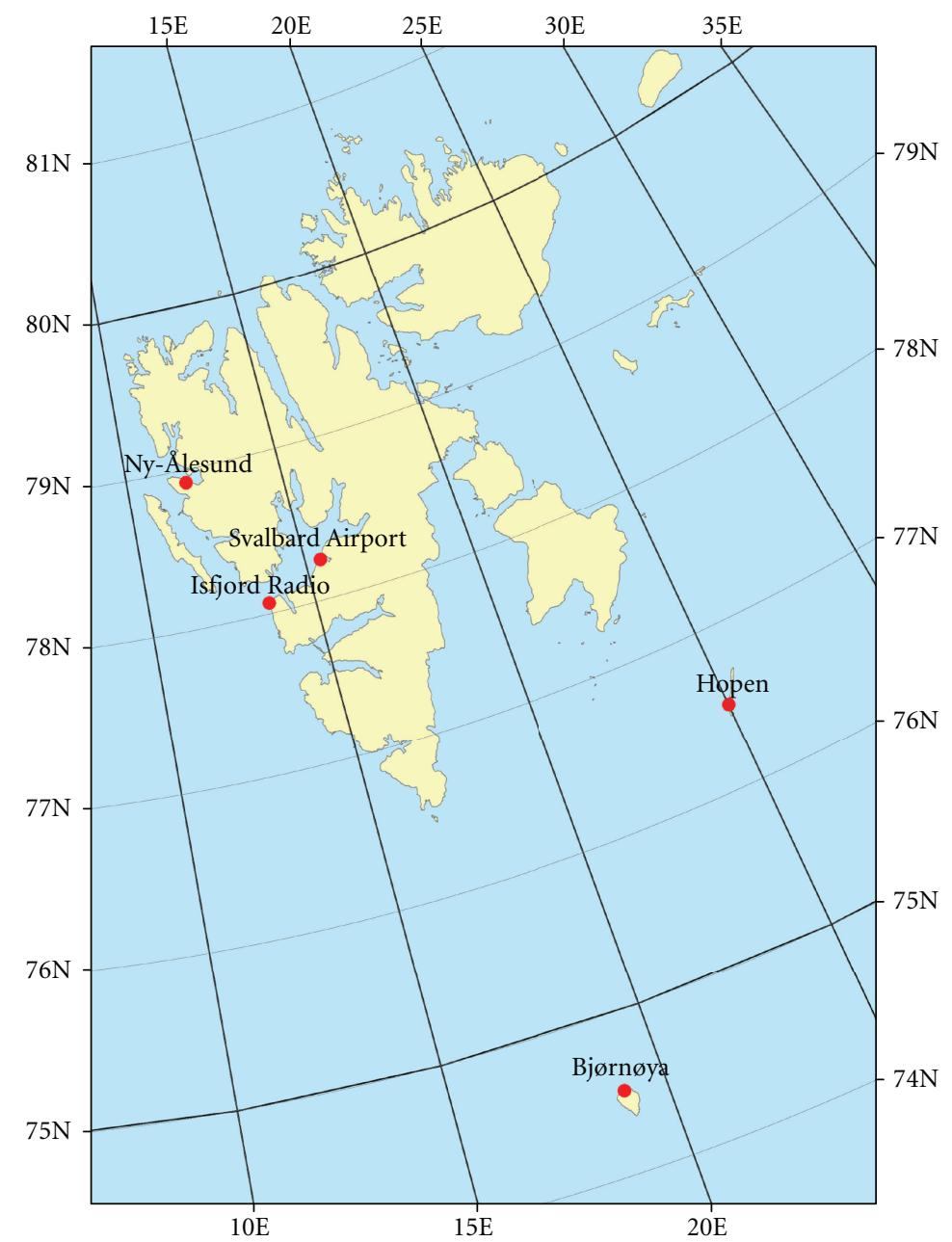

FIGURE 1: Map of the Svalbard region including weather stations used in the analysis.

TABle 1: Average annual and seasonal temperatures ( $\left.{ }^{\circ} \mathrm{C}\right)$ during $1961-90$ and 1981-2010.

\begin{tabular}{|c|c|c|c|c|c|c|c|c|c|c|}
\hline \multirow{2}{*}{ Station } & \multicolumn{5}{|c|}{$1961-1990$} & \multicolumn{5}{|c|}{$1981-2010$} \\
\hline & Annual & Winter & Spring & Summer & Autumn & Annual & Winter & Spring & Summer & Autumn \\
\hline Ny-Ålesund & -6.3 & -13.8 & -9.8 & 3.4 & -5.3 & -5.2 & -12 & -8.5 & 3.8 & -4.4 \\
\hline Svalbard Airport & -6.7 & -15.1 & -10.8 & 4.2 & -5.2 & -4.6 & -11.7 & -8.3 & 5.2 & -3.5 \\
\hline Hopen & -6.4 & -13.4 & -9.9 & 1.3 & -3.8 & -4.3 & -9.9 & -7.6 & 2.3 & -1.9 \\
\hline Bjørnøya & -2.4 & -7.6 & -4.8 & 3.5 & -0.5 & -0.9 & -5.1 & -3.4 & 4.4 & 0.6 \\
\hline
\end{tabular}

Bjørnøya during summer 1966-88. The annual temperature increase at Svalbard Airport and Hopen during the latest two decades is close to $1.2^{\circ} \mathrm{C}$ per decade, and the warming during the winter season $\left(2-3^{\circ} \mathrm{C}\right.$ per decade $)$ is substantially higher than during the "early 20th century warming."

The trends for the optimal series (Table 2, bottom) show that the annual mean temperature has increased significantly in the Svalbard Airport/Longyearbyen area since 1912. The linear trend indicates an increase in mean annual temperature of $2.5^{\circ} \mathrm{C}$ during the latest 100 years, which is about three times the estimated global warming [2] during the same period. The warming has also accelerated considerably since the increase of $0.14^{\circ} \mathrm{C}$ per decade from 1912 to 2000 reported by Hanssen-Bauer [13]. Also at Bjørnøya and Hopen, there are statistically significant positive trends in annual temperatures for the optimal series. The composite Ny-Ålesund series starts in the relatively warm 1930s, and thus there is no statistically significant warming in the optimal annual series from this station.

For the optimal series, all stations have statistically significant warming trends $\left(0.27-0.46^{\circ} \mathrm{C}\right.$ per decade) during spring. This reflects the fact that spring temperatures have 


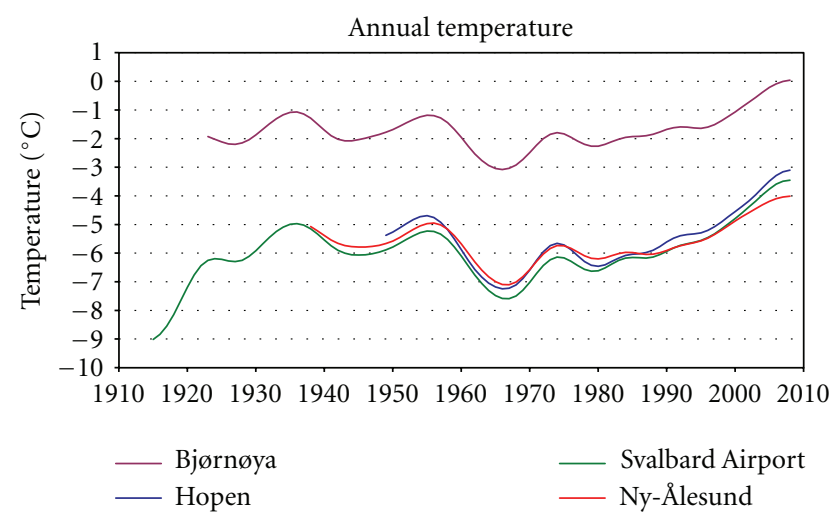

Figure 2: Annual temperature development at weather stations in the Svalbard region. The lowpass filtered series are smoothed by Gaussian weighting coefficients and show variability on a decadal time scale. The curves are cut three years from start and end.

increased more evenly throughout the century than, for example, the winter temperature. During 1912-2011 pronounced warming (statistically significant at the 5\% level) at Svalbard Airport has occurred in spring, summer, and autumn.

For the period 1975-2011, it is possible to compare recent trends when all stations were running at the present sites. The linear trends in Table 2 indicate that during this 37year period, the annual temperature at the four stations has increased by $2.7-4.0^{\circ} \mathrm{C}$, and the winter temperature by $4.8-$ $6.5^{\circ} \mathrm{C}$.

2.2. Precipitation. Observations suggest that total annual precipitation has increased by roughly $14 \%$ in the Arctic north of $60^{\circ} \mathrm{N}$ over the past century [1]. The greatest increases were observed in autumn and winter. However, uncertainties in measuring precipitation in the harsh Arctic environment [22] and the sparseness of data in parts of the region limit confidence in these results. There are large regional variations in precipitation across the Arctic, and also large regional variations in the changes in precipitation. According to ACIA [1], the precipitation increased by about $2 \%$ per decade during the Arctic warming in the first half of the 20th century (1900-1945), with significant trends in the Nordic region. During the two decades of Arctic cooling (1946-1965), the high latitude precipitation increase was roughly $1 \%$ per decade. Since 1966 , annual precipitation has increased at about the same rate as during the first half of the 20th century. Also, IPCC [2] states that there has been a widespread increase in precipitation over northernmost Europe during 1900-2005.

The harsh weather conditions (e.g., blowing and drifting snow, undercatch in precipitation gauges during snowfall, and high wind speeds) complicate precipitation measurements in the Arctic [10, 13, 22]. To reduce inhomogeneities because of instrumental changes, manual precipitation measurements are still performed at the stations used in this paper. Studies of long-term precipitation variability in the Svalbard region are hampered by several relocations of

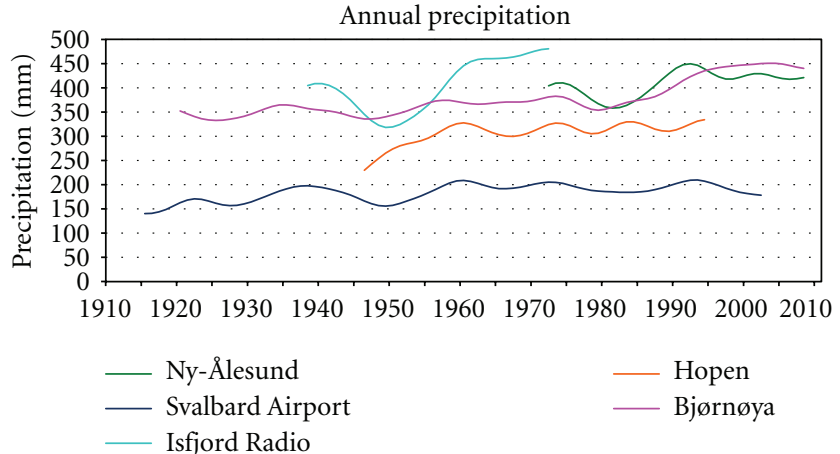

FIGURE 3: Annual precipitation development at weather stations in the Svalbard region. The lowpass filtered series are smoothed by Gaussian weighting coefficients and show variability on a decadal time scale. The curves are cut three years from start and end.

gauges. The precipitation gauge in Longyearbyen was moved to Svalbard Airport in 1975, but based on measurements at several sites, a composite, homogenised precipitation series back to 1912 was established by Nordli et al., 1996 [11]. However, this series is not homogenised after a new relocation in 2005. Also the Hopen series are not homogenised after relocation of the precipitation gauge in 1997.

The average annual precipitation at Ny-Ålesund is more than twice as high as at Svalbard Airport (Table 3). At Svalbard Airport and Ny-Ålesund, the recent average spring and summer precipitation is slightly lower than during the standard normal period 1961-1990, while there is an increase during autumn and winter. For Ny-Ålesund and Bjørnøya, the average annual precipitation during $1981-2010$ is $10 \%$, respectively, 20\% higher than during 1961-1990.

The precipitation series from the Norwegian high-Arctic stations show quite different individual long-term patterns both on an annual as well as a decadal timescale (Figure 3). This is in contrast to the quite similar development for temperature, and the main reason is that precipitation varies locally on a smaller spatial scale than air temperature. However, the series have one common feature: all series show a positive trend in annual precipitation throughout the period of observations (cf. Table 4). Hanssen-Bauer and Førland [15] showed that the precipitation trend at Svalbard Airport from 1912 to the 1990s to a large degree could be explained by variations in the atmospheric circulation in the same period. The trends in annual precipitation at Svalbard Airport and Bjørnøya are statistically significant even at the $1 \%$ level. At Svalbard Airport, the annual measured precipitation has in average increased by $2 \%$ per decade, while the increase at Bjørnøya and Ny-Ålesund is 3-4\% per decade. At Svalbard Airport, the summer and autumn precipitation show a pronounced increase (statistically significant at the $5 \%$ level), while on Bjørnøya, a marked increase has taken place during winter, spring, and autumn, (Table 4). During 1975-2011 when the measurements at Bjørnøya and NyÅlesund were performed at the present sites; positive trends are found for annual, autumn, and winter precipitation (Table 4, bottom). 
TABLE 2: Linear temperature trends ( ${ }^{\circ} \mathrm{C}$ per decade) in different time periods for stations in the Svalbard region. Trends significant at the $5 \%$ level are bold (Mann-Kendall nonparametric test [21]).

\begin{tabular}{|c|c|c|c|c|c|c|}
\hline & Location & Annual & Winter & Spring & Summer & Autumn \\
\hline \multirow{2}{*}{$1920-1942$} & Svalbard Airport* & 0.34 & 1.23 & 0.09 & -0.28 & 0.47 \\
\hline & Bjørnøya & 0.14 & -0.55 & -0.35 & 0.18 & 0.66 \\
\hline \multirow{3}{*}{ 1943-1965 } & Ny-Ålesund* & -0.26 & -1.48 & 0.07 & 0.04 & 0.39 \\
\hline & Svalbard Airport* & -0.35 & -1.76 & -0.22 & -0.00 & 0.58 \\
\hline & Bjørnøya & -0.33 & -0.91 & -0.19 & -0.29 & 0.14 \\
\hline \multirow{4}{*}{$1966-1988$} & Ny-Ålesund* & 0.38 & 0.54 & 0.73 & 0.10 & 0.51 \\
\hline & Svalbard Airport* & 0.52 & 0.72 & 0.96 & 0.27 & 0.48 \\
\hline & Hopen & 0.26 & 0.00 & 0.49 & 0.14 & 0.57 \\
\hline & Bjørnøya & 0.34 & 0.53 & 0.71 & -0.03 & 0.36 \\
\hline \multirow{4}{*}{ 1989-2011 } & Ny-Ålesund & 0.99 & 2.52 & 0.46 & 0.50 & 0.78 \\
\hline & Svalbard Airport & 1.25 & 2.88 & 0.60 & 0.76 & 1.14 \\
\hline & Hopen & 1.21 & 2.89 & 0.46 & 0.18 & 1.50 \\
\hline & Bjørnøya & 0.91 & 2.01 & 0.86 & 0.32 & 1.14 \\
\hline $1975-2011$ & Ny-Ålesund & 0.73 & 1.36 & 0.60 & 0.33 & 0.53 \\
\hline 1975-2011 & Svalbard Airport & 1.04 & 1.66 & 0.98 & 0.55 & 0.86 \\
\hline 1975-2011 & Hopen & 1.10 & 1.76 & 1.02 & 0.43 & 1.00 \\
\hline 1975-2011 & Bjørnøya & 0.76 & 1.30 & 0.59 & 0.39 & 0.62 \\
\hline 1935-2011 & Ny-Ålesund* & 0.11 & -0.02 & 0.27 & 0.09 & 0.07 \\
\hline 1912-2011 & Svalbard Airport* & 0.25 & 0.25 & 0.46 & 0.11 & 0.19 \\
\hline 1946-2011 & Hopen & 0.31 & 0.31 & 0.44 & 0.22 & 0.23 \\
\hline 1920-2011 & Bjørnøya & 0.11 & 0.02 & 0.29 & 0.08 & 0.05 \\
\hline
\end{tabular}

* The Svalbard Airport and Ny-Ålesund series are homogenised composites from other sites before 1975, respectively, 1969 [11].

TABLE 3: Average precipitation totals (in millimetres) during 1961-90 and 1981-2010.

\begin{tabular}{lcccccccccc}
\hline \multirow{2}{*}{ Station } & \multicolumn{3}{c}{ 1961-1990 } & \multicolumn{4}{c}{ 1981-2010 } \\
& Annual & Winter & Spring & Summer & Autumn & Annual & Winter & Spring & Summer & Autumn \\
\hline Ny-Ålesund & 385 & 99 & 86 & 84 & 116 & 427 & 132 & 78 & 82 & 136 \\
Svalbard Airport* & 190 & 52 & 40 & 51 & 49 & 191 & 55 & 31 & 47 & 58 \\
Hopen & 476 & 135 & 97 & 104 & 140 & NA & NA & NA & NA & NA \\
Bjørnøya & 369 & 92 & 67 & 89 & 121 & 442 & 135 & 94 & 78 & 136 \\
\hline
\end{tabular}

* The relocation of the gauge at Svalbard Airport in 2005 has minor influence on the 30-year average 1981-2010.

Though the long-term trends in annual precipitation tend to be positive at the Svalbard stations, the precipitation level seems to have been rather constant during the latest two decades (Figure 3), in spite of the fact that temperatures have continued to rise. This may have connection with the regime shift in the large-scale atmospheric circulation in the area, suggested by Overland and Wang [17].

\section{Downscaling of Global Climate Models in the Norwegian Arctic}

The comprehensive atmosphere ocean general circulation models (AOGCMs) are the most sophisticated tools available for projecting global climate development. These models provide a description of atmospheric, oceanic, sea ice, and often land surface processes in terms of a set of equations describing the essential physics and dynamics.
Different AOGCMs give differences in climate projections, and the major reason for this is different initial conditions, resolutions, and differences in parameterizations [2]. At higher latitudes, the natural variability is large and can explain much of the differences in AOGCM simulations [23]; however, the differences between different models can partly be attributed to the earth's geometry, lower degrees of freedom, and sampling fluctuations [24]. Another reason for the high climate variability in the Arctic is feed-back mechanisms connected to snow and ice.

The resolution in the AOGCMs is presently probably sufficient for modelling most of the large-scale features, but in general still too coarse to enable these models to reproduce the climate on regional or local scale. When more detailed climate data are needed, for example for impact studies, output from AOGCMs can be downscaled by dynamical or statistical techniques. An important (though not the only) 
TABle 4: Linear precipitation trends (\% per decade) in the Svalbard region. Trends significant at the 5\% level are bold. The statistical significance of the trends was tested by the Mann-Kendall nonparametric test [21]. The trend analysis for Svalbard Airport and Hopen do not include the latest years because of relocation of gauges. Absolute trends in millimetres may be deduced by combining with the 1961-1990 averages in Table 3.

\begin{tabular}{|c|c|c|c|c|c|c|}
\hline Station & Period & Annual & Winter & Spring & Summer & Autumn \\
\hline Ny-Ålesund & 1969-2011 & 4.2 & 8.9 & 0.2 & -3.6 & 9.1 \\
\hline Svalbard Airport* & $1912-2005$ & 1.9 & -0.3 & 1.5 & 3.1 & 3.4 \\
\hline Isfjord Radio & $1935-1975$ & 8.0 & 11.2 & 8.4 & 8.5 & 9.6 \\
\hline Hopen & 1946-1997 & 4.6 & 7.1 & 7.2 & 2.9 & 1.3 \\
\hline Bjørnøya & $1920-2011$ & 3.3 & 4.6 & 5.6 & 0.8 & 2.7 \\
\hline Ny-Ålesund & $1975-2011$ & 5.4 & 15.6 & -2.7 & -5.1 & 10.9 \\
\hline Bjørnøya & $1975-2011$ & 9.4 & 13.3 & 15.1 & 2.0 & 8.8 \\
\hline
\end{tabular}

* The Svalbard Airport series is a homogenised composite from other locations before 1975 [11].

condition for making realistic local climate projections, is that the AOGCM used for downscaling gives a reasonably good description of the present climate in the Arctic. Though no single AOGCM can be said to be "best" to use in an assessment of the Arctic, Walsh et al. [25] have evaluated and ranked 15 of the IPCC [2] models according to their ability to reproduce the observed sea level pressure, temperature, and precipitation.

3.1. Regional Climate Models (Dynamical Downscaling). Output from AOGCMs can be used to drive regional climate models (RCMs) that have more detailed process representations compared to AOGCMs in addition to a much higher spatial resolution. The regional climate model HIRHAM has earlier been applied over the Nordic region [26] and in a transient climate simulation over Greenland and adjacent seas [27]. Successful implementation of an RCM depends on a number of conditions, for example, nesting strategy, domain size, difference in resolution between the AOGCM and RCM, the physical parameterisations, quality of the driving data, and spinup time. Generally, an RCM cannot be expected to improve errors in the AOGCM results on a large scale but should be able to develop small-scale features, at least due to more realistic surface forcing. As for its global counterpart, it is certainly necessary to realistically simulate present climate. Observed data can then be used for validation, as a first attempt to trust the output from climate change experiments.

Most European and Nordic RCM simulations do not cover the Norwegian Arctic, for example, in the large European ENSEMBLES project (www.ensembles-eu.org), the northern border for the domain was just north of the Norwegian mainland. A new regional climate model (NorACIA-RCM, spatial resolution $25 \times 25 \mathrm{~km}$ ) focussing on the Svalbard region was therefore established [28]. To evaluate whether the NorACIA-RCM gave a realistic description of the climate within the model domain, the RCM was run with input from a reanalysis dataset (ERA40) covering the period 1958-2002 [29]. The conclusion of comprehensive NorACIA-validations was that the presentday simulations gave a reasonable description of the observed daily precipitation and temperature climate in the region [28]. It is worth mentioning that the climate signal around Svalbard is highly sensitive to the seasonal cycle in sea surface temperature and ice cover. In the NorACIA-RCM, this was specified from the global coupled ECHAM4/OPYC sea-ice module but modified around Svalbard due to more realistic representation of land-sea mask in the RCM.

The spatial resolution of RCMs is too coarse to provide representative information on a local scale. Empirically adjustment of the RCM output is therefore necessary to obtain site-specific projections. Different methods are available, for example, delta change methods, transformation of distribution functions, and so forth. In this study, local series of daily temperature and precipitation were derived from the RCMs as described by Engen-Skaugen [30]. This method applies monthly adjustment factors for the mean value and variance based on differences between daily values from RCM control runs and observations of temperature and precipitation for "the control period" (1961-1990).

\subsection{Empirical/Statistical Downscaling. Empirical-Statistical} downscaling (ESD) identifies empirical links between largescale patterns of climate elements (predictors) and local climate (predictands), which are then used to predict local changes from the output from global or regional climate models. Successful downscaling depends on the following conditions: (1) the climate model should reproduce the large-scale predictor fields realistically, (2) the predictors should account for a major part of the variance in the predictands, (3) the links between predictors and predictands should be stationary, and (4) when applied in a changing climate, predictors that "carry the climate signal" should be included [31].

The philosophy behind empirical downscaling is that the local climate partly is a result of local conditions that are quite constant (e.g., topography and vegetation), and partly of large-scale weather patterns. In a comparison of results from empirical downscaling and regional climate modelling for Scandinavia, Hanssen-Bauer et al. [32] concluded that there were few statistically significant differences between the results. Empirical downscaling may catch several local 
features that are not "resolved" in the present regional climate models. On the other hand, the regional climate models provide better temporal resolution as well as a number of climate variables which the empirical downscaling is not able to reproduce. Another limitation is that basically the empirical downscaling may just be used for localities with observational time series long enough to develop robust relationships between local climate and large-scale patterns. However, it is possible to add information in space through geographical interpolation based on ESD results for single sites [33]. Description of methodology and results for the empirical-statistical downscaling for the Norwegian Arctic are published in Benestad [34, 35] and Førland et al. [28, 36].

The ESD analysis for the Norwegian Arctic incorporated multimodel dataset (MMD) ensembles based on 48 integrations for temperature and 43 for precipitation. This model ensemble includes both simulations for the 20th century $(20 \mathrm{C} 3 \mathrm{M})$ and scenario runs for the 21 st century following the emission scenarios AlB [37]. The analysis performed by Benestad [34] involved new ways of combining observations from the 20th century with projections for the 21 st century, and a quality control was used to "weed out" global climate models with a poor reproduction of present climate. The results were found to be sensitive to the choice of predictor domain, but smaller domains were taken to be more reliable. Some of the AOGCMs have been used to make several parallel runs, differing only by using different initial conditions (starting point). The ESD was applied to the MMD ensemble for both the 20th century and the 21st century simulations separately.

\section{Climate Projections for the 21st Century}

4.1. Air Temperature. Earlier temperature projections for the Arctic [1] indicate that by the end of the 21st century, Arctic mean annual temperature increases are $7^{\circ} \mathrm{C}$ and $5^{\circ} \mathrm{C}$ for the $\mathrm{A} 2$ and $\mathrm{B} 2$ emission scenarios [37], respectively, compared to the present climate. The multimodel dataset used in the regional climate projections for IPCC [2] projected an annual warming of the Arctic of $5^{\circ} \mathrm{C}$ at the end of the 21st century, but with a considerable across-model range of $2.8^{\circ} \mathrm{C}$ to $7.8^{\circ} \mathrm{C}$. Over both ocean and land, the largest warming is projected in winter, and the smallest in summer. By the end of the century, the mean warming in the IPCC [2] projections ranges from $4.3^{\circ} \mathrm{C}$ to $11.4^{\circ} \mathrm{C}$ in winter and from $1.2^{\circ} \mathrm{C}$ to $5.3^{\circ} \mathrm{C}$ in summer under the $\mathrm{A} 1 \mathrm{~B}$ emission scenario.

The NorACIA-RCM was run for the Norwegian Arctic with input from six AOGCM simulations (cf. Table 5), while ca. 50 ESD projections [35] were performed for the weather stations in the Svalbard region based on the CMIP3 ensemble of global model runs [7]. Figure 4(a) shows projected spatial changes in mean annual temperature for the MPIB2 simulation. The results in Figure 5 demonstrate that this simulation is close to the median value for the 50 ESD-integrations. Figure 4(a) indicates that up to the end of this century, there will be an increase in annual temperature of $1.5-2.0^{\circ} \mathrm{C}$ southwest of Spitsbergen. The largest increase $\left(6-8^{\circ} \mathrm{C}\right)$ is projected for the north-eastern parts of Svalbard, and between Spitsbergen and Novaja Zemlja. The smallest seasonal changes (not shown) are projected for the mean summer temperature. For autumn, winter, and spring, a large increase is projected east and northeast of Svalbard. The projected decrease in sea-ice coverage will largely influence the temperature in the lower atmosphere, and this is the main reason for the large gradient in temperature increase from south-western to north-eastern parts of the Svalbard region.

For comparison with the station-based ESD-values, the results from the six RCM-simulations (Table 5) were interpolated to the locations of the Svalbard weather stations [36]. The quality of the ESD-results for the Arctic depends on the realism both in the re-analysed datasets and in the AOGCMs [35]. The climate description in the re-analyses may be misleading because of the scarcity in observations from the Arctic [38].

For most of the stations analysed in the Svalbard region, there was good accordance between the ESD and RCMsimulations $[28,36]$. Combined results from the ESD and RCM simulations are shown in Figure 5 for Svalbard Airport/Longyearbyen. The thick line represents the ensemble median for the 48 ESD simulations. The coloured symbols indicate that most of the median values based on interpolated RCM values are quite close to the ESD median. The vertical bars give a measure for how the year-to-year variability is reproduced in the RCM simulations. The pink region indicates the 5-95 percentile range of the intermodel and internal variations in the ESD simulations. The large spread is mostly due to the pronounced interannual variability that characterises the Arctic and also reflects intermodel (AOGCM) differences. These results provide a basis for describing uncertainties associated with the projections [33]. The figure also illustrates that temperatures which in present climate would have been characterised as "extremely high" will according to these results be found in the lower part of the temperature distribution for the end of this century.

The ESD simulations for the period 1900-2000 are carried out for historical runs $(20 \mathrm{C} 3 \mathrm{M})$ where the AOGCMs have been forced with observed emissions. As the RCM and ESD results are presented as 5-95\% intervals, it should be expected that about $90 \%$ of the observation-based values (black dots) should be inside the hatched area if the models are able to reproduce the variance realistically. For Svalbard Airport (Figure 5), this mostly seems to be the case. However, it seems as if the ESD models are not able to reproduce the warmest winters during the 1930s to 1950s, nor the coldest seasons.

To compare modelled and observed historical trends, a linear trend fit was carried out for each realisation of the downscaled CMIP3 run that had results for both the 20th and 21 st centuries. The trends associated with the ESD results were estimated for the same time interval as the optimal observational series from Svalbard Airport/Longyearbyen (Table 2). The CMIP3 trend distribution was approximately normally distributed according to a normal quantilequantile plot, and a normal probability distribution function (PDF) was, therefore, used to estimate the similarity between the observed linear trends and corresponding downscaled trends. The PDFs are shown in Figure 6, together with the observed trend. The probabilities shown under each 


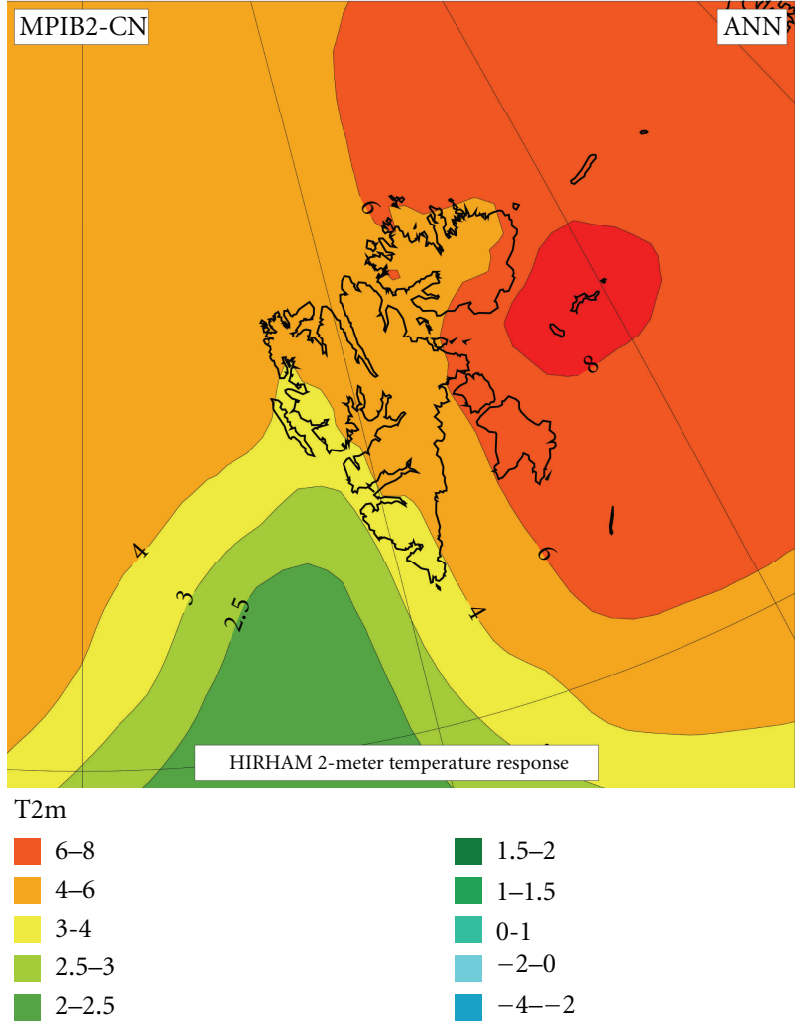

(a)
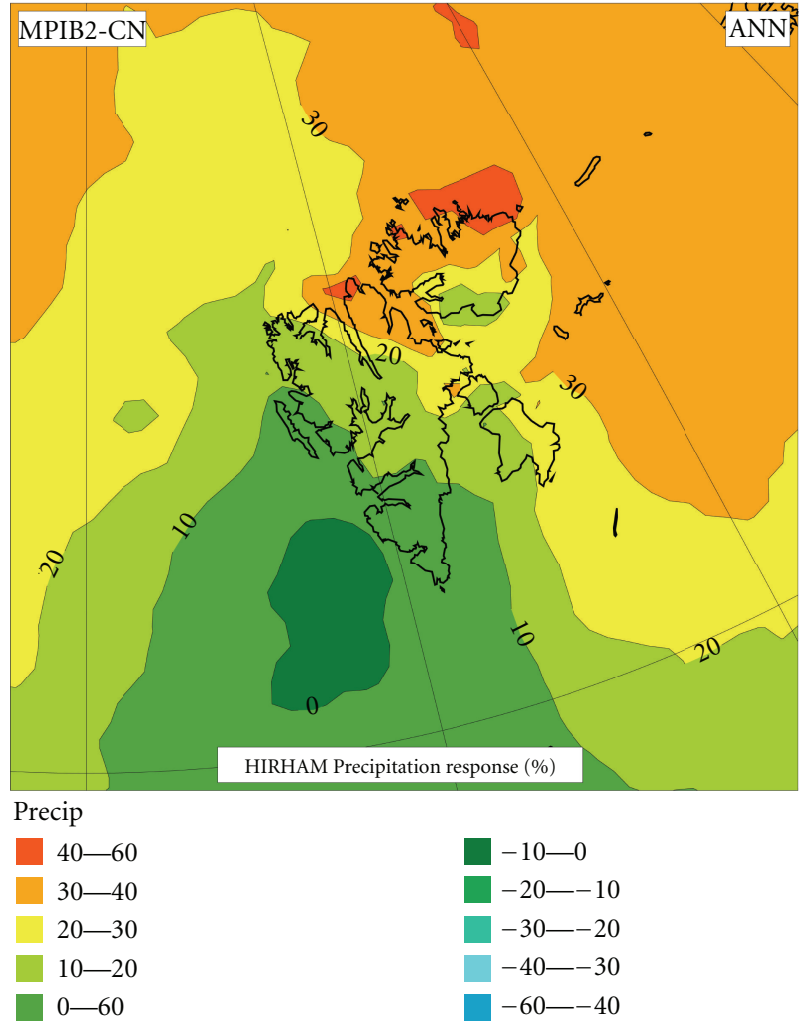

(b)

Figure 4: Projected changes from 1961-90 to 2071-2100 in (a) mean annual temperature ( $\left.{ }^{\circ} \mathrm{C}\right)$, (b) mean annual precipitation (\%). The RCM projections are based on MPIB2 (cf. Table 5).

TABLE 5: RCM simulations for the Svalbard region. The simulations were performed by the regional climate model HIRHAM2/NorACIA [28].

\begin{tabular}{|c|c|c|c|c|c|}
\hline \multirow{2}{*}{ Global model } & \multirow{2}{*}{$\begin{array}{c}\text { Emission } \\
\text { scenario [35] }\end{array}$} & \multicolumn{2}{|c|}{ Control } & \multicolumn{2}{|c|}{ Scenario } \\
\hline & & Period & Acronym & Period & Acronym \\
\hline Max-Planck Inst. & IS92a & $1981-2010$ & MPI92a & 2021-2050 & MPI92b \\
\hline ECHAM4 & SRES B2 & $1961-1990$ & MPICN & $2071-2100$ & MPIB2 \\
\hline Hadley Centre & SRES A2 & $1961-1990$ & HADCN & $2071-2100$ & HADA2 \\
\hline HadAM3H & SRES B2 & 1961-1990 & HADCN & $2071-2100$ & HADB2 \\
\hline Hadley Centre & SRES A1 B & $1961-1990$ & HADA1 & 2021-2050 & HADA1b \\
\hline HadCM3 & SRES A1B & $1961-1990$ & HADA1 & 2071-2099 & HADA1c \\
\hline
\end{tabular}

panel indicate which quantile in the downscaled results that matches the observed trend. For all seasons, the observed trend falls within the 10-90 confidence interval, suggesting that the downscaled results do span the observations. This comparison constitutes an evaluation of the downscaled warming trends for the past from the CMIP3 runs, but it does not validate the realism in trends for the future. The large spread in modelled historical trends indicates that the CMIP3 ensemble contains some models with unrealistic results for the Svalbard region and implies that large uncertainties are linked to projected trends for future climate.
Projected changes in percentiles of annual and seasonal temperatures for the ensembles of ESD (48 members) and RCM (4 members valid for 2071-2100) simulations are summarised in Table 6. The RCM data was calibrated before computation of percentiles; for each pair of control/scenario, the data were adjusted from the difference between the control and the mean of all control simulations 1961-1990. For Svalbard Airport/Longyearbyen, the 50-percentiles for annual mean temperatures indicate an increase of almost $7^{\circ} \mathrm{C}$ from 1961-1990 to 2071-2100. For winter temperatures, the 50 -percentile is around $10^{\circ} \mathrm{C}$ higher in the $2071-2100$ period. The increases in the annual 50-percentile at Bjørnøya in the 

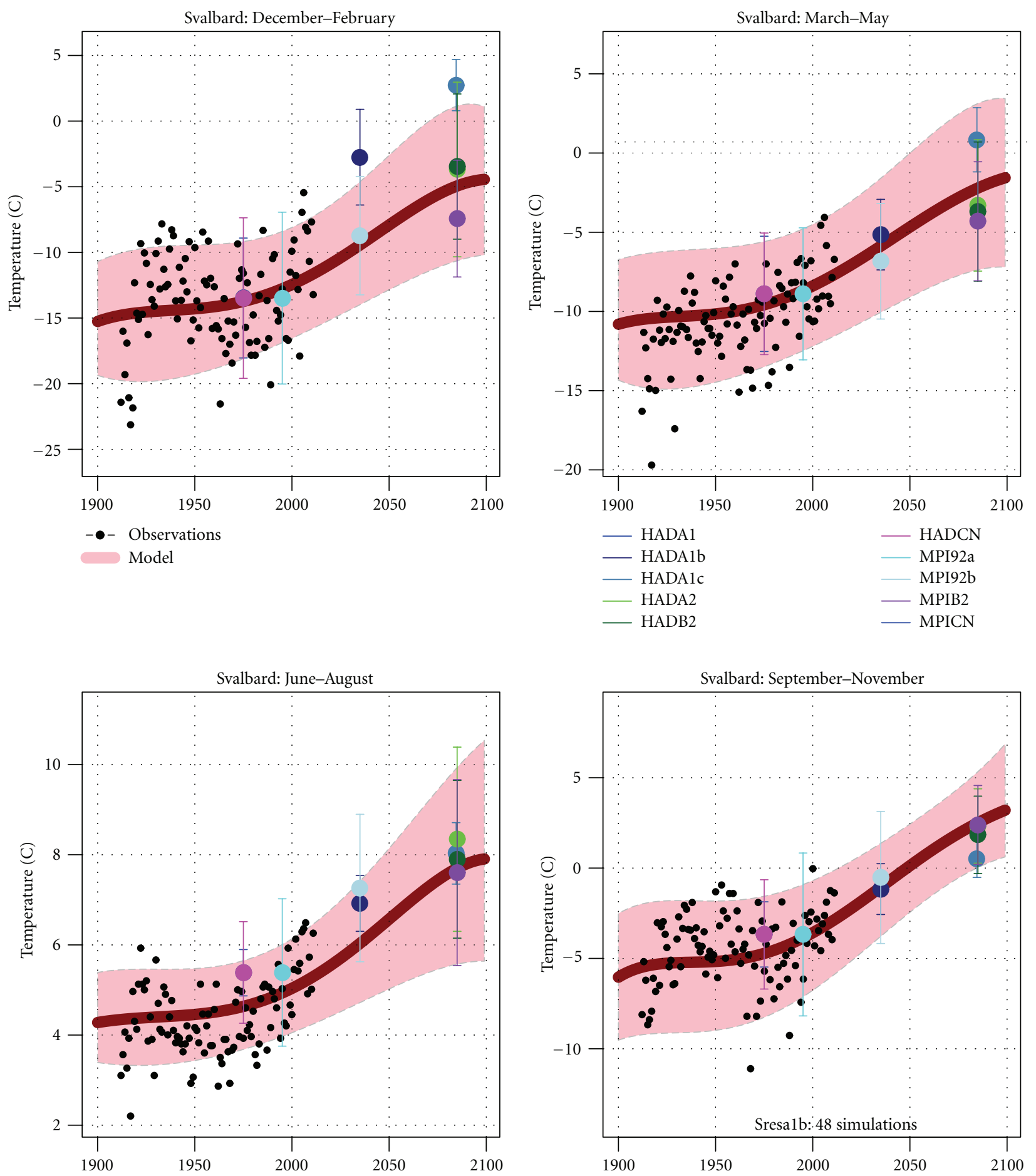

FIGURE 5: Temperature projections for Svalbard Airport/Longyearbyen: results from ESD and RCM downscalings for winter, spring, summer, and autumn. The hatched area (pink) shows 5\% and 95\% interval from ESD estimates, the black dots show observed values, and the thick line (red) show median (50\%) value for the ESD ensemble. The coloured symbols indicate the median value for the different runs with NorACIA-RCM, and the vertical lines show the 5- and 95-percentiles for the RCM runs. The RCM values are plotted on the central year in the respective time slices. For acronyms, see Table 5. 


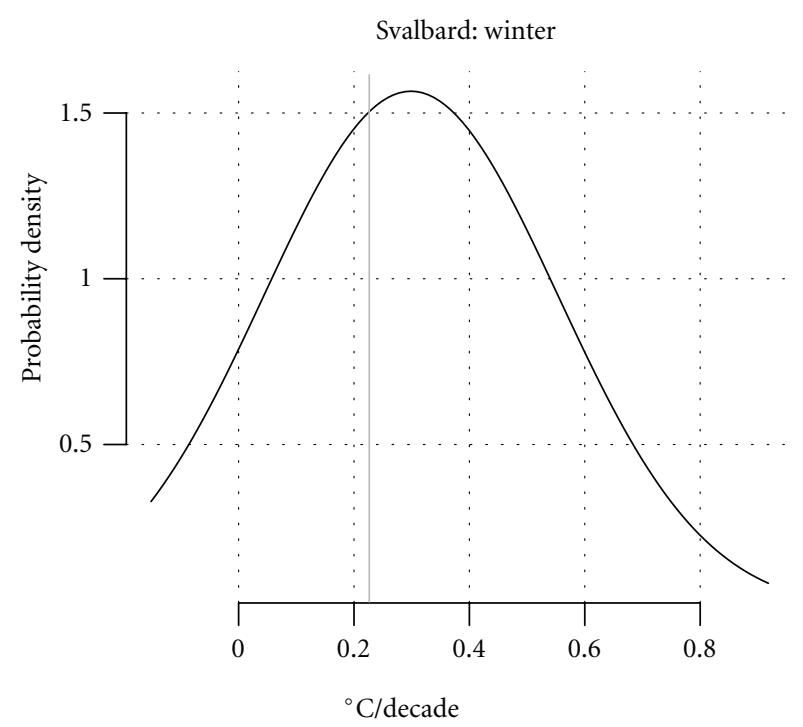

Period: $1912-2010 \mathrm{~N}(\mathrm{GCMs})=43 \operatorname{Pr}(X<x)=39 \%$

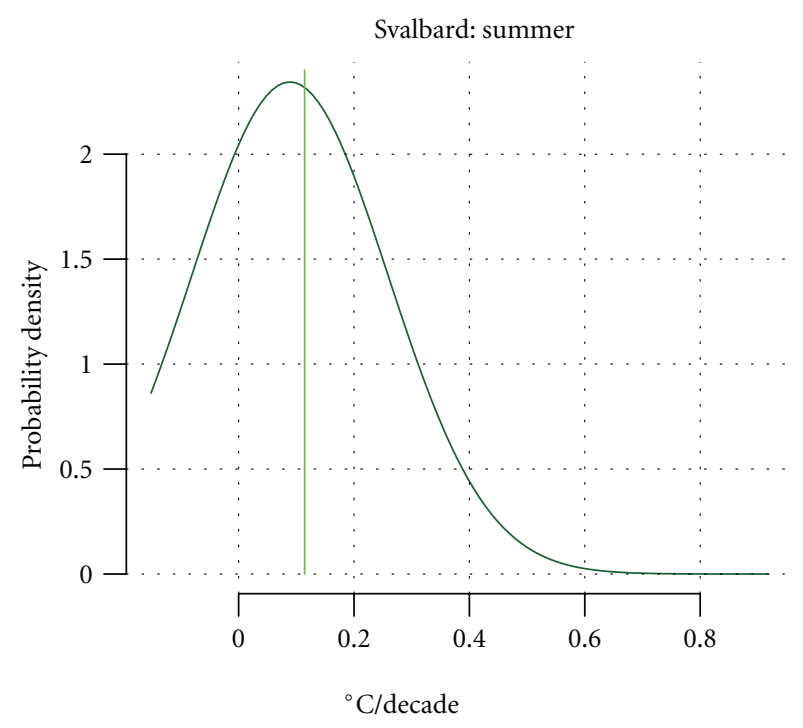

Period: $1912-2010 \mathrm{~N}(\mathrm{GCMs})=43 \operatorname{Pr}(X<x)=67 \%$

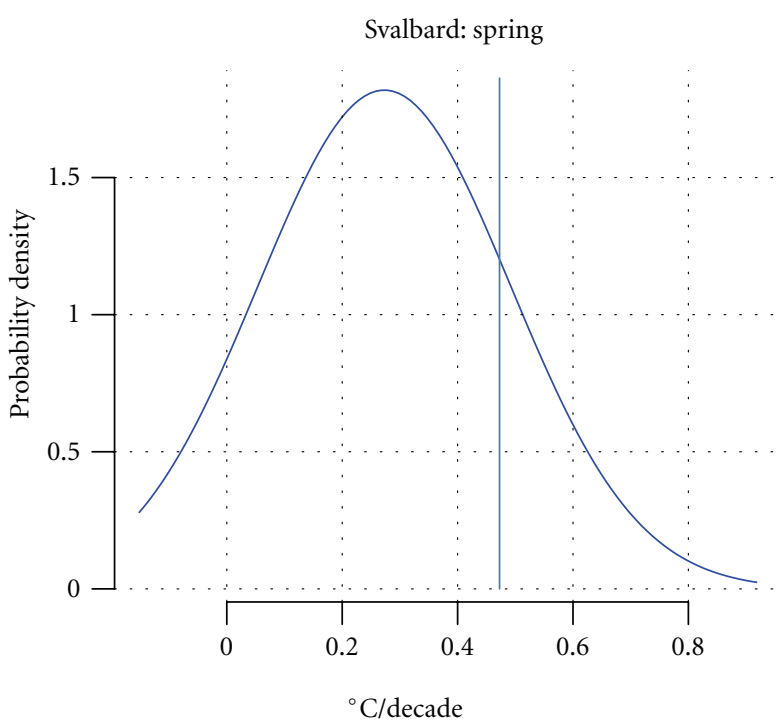

Period: $1912-2010 \mathrm{~N}(\mathrm{GCMs})=43 \operatorname{Pr}(X<x)=82 \%$

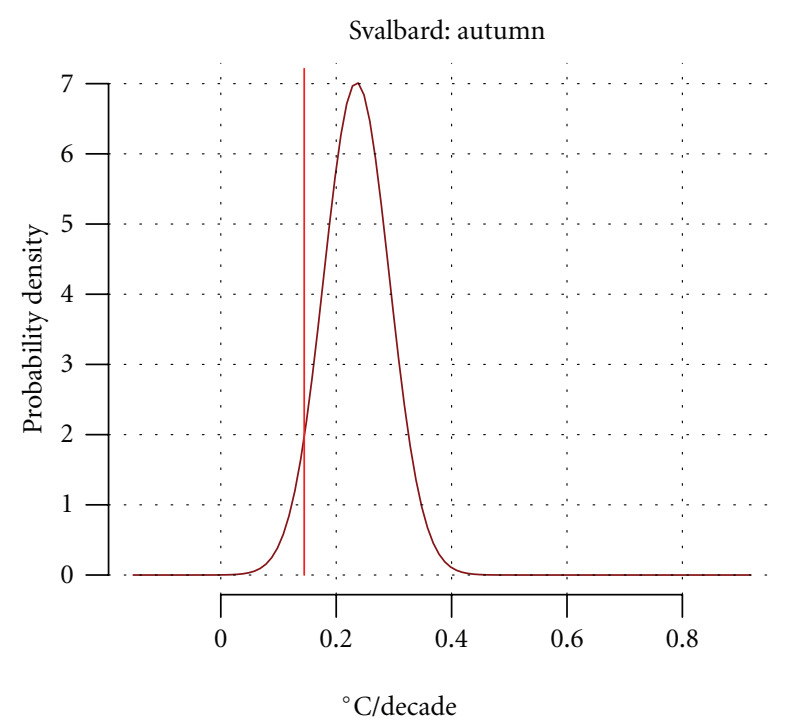

Period: $1912-2010 \mathrm{~N}(\mathrm{GCMs})=43 \operatorname{Pr}(X<x)=30 \%$

FIGURE 6: Comparison of downscaled and observed trends for the 1912-2010 period. The curve shows the probability density function of the downscaled results from 43 ESD simulations and the vertical line the observed trend. The probability (Pr) signifies the quantile in the PDF matching the observed trend.

ESD and RCM-ensembles are 6.2 and $4.1^{\circ} \mathrm{C}$, respectively. While the large ESD ensemble indicates the highest increase for the 95-percentile temperatures, the picture is more mixed in the smaller RCM ensemble. But both ensembles indicate a substantial increase $\left(\sim 12^{\circ} \mathrm{C}\right)$ in the upper $5 \%$ of the winter season temperatures in the Longyearbyen area.

4.2. Precipitation. The ACIA [1] climate projections for the Arctic $\left(60-90^{\circ} \mathrm{N}\right)$ indicate an annual total precipitation increase by roughly $12 \%$ from $1981-2000$ to $2071-2090$. IPCC [2] states that increase in the amount of precipitation is very likely at high latitudes. The spatial pattern of the projected precipitation change [2] shows the greatest percentage increase over the Arctic Ocean (30 to 40\%) and the smallest (and even a slight decrease) over the northern North Atlantic $(<5 \%)$. By the end of the 21 st century, the projected change in the annual mean Arctic precipitation for the A1B emission scenario varies from 10 to $28 \%$, with an ensemble median of $18 \%$. The percentage precipitation increase is largest in winter and smallest in summer, consistent with the projected warming.

The projected increase in annual precipitation based on the RCM simulation MPIB2 (Figure 4(b)) shows an increase from a few percent southwest of Spitsbergen to more than $40 \%$ in the north-eastern parts of the archipelago. The spatial pattern of changes in precipitation is quite 
TABle 6: Projected changes in 5-, 50-, and 95-percentile annual and seasonal temperatures ( $\left.{ }^{\circ} \mathrm{C}\right)$ from $1961-90$ to 2071-2100 for Svalbard Airport and Bjørnøya.

(a) Empirical-statistical downscaling.

\begin{tabular}{lcccccccccc}
\hline \multirow{2}{*}{ Percentile } & \multicolumn{9}{c}{ Svalbard Airport/Longyearbyen } & \multicolumn{5}{c}{ Bjørnøya } \\
& Annual & Winter & Spring & Summer & Autumn & Annual & Winter & Spring & Summer & Autumn \\
\hline $5 \%$ & 4.7 & 6.9 & 6.0 & 1.5 & 5.9 & 5.2 & 8.0 & 6.7 & 2.4 & 4.7 \\
$50 \%$ & 6.8 & 9.4 & 7.6 & 2.5 & 7.3 & 6.2 & 7.8 & 7.6 & 3.9 & 5.2 \\
$95 \%$ & 8.5 & 11.4 & 9.5 & 3.9 & 9.5 & 9.0 & 12.7 & 9.9 & 6.4 & 7.1 \\
\hline
\end{tabular}

(b) Regional climate models.

\begin{tabular}{lcccccccccc}
\hline \multirow{2}{*}{ Percentile } & \multicolumn{9}{c}{ Svalbard Airport/Longyearbyen } & \multicolumn{5}{c}{ Bjørnøya } \\
& Annual & Winter & Spring & Summer & Autumn & Annual & Winter & Spring & Summer & Autumn \\
\hline $5 \%$ & 4.8 & 8.1 & 5.3 & 2.0 & 6.4 & 4.8 & 8.9 & 5.2 & 2.6 & 3.1 \\
$50 \%$ & 6.6 & 10.4 & 6.4 & 2.8 & 5.6 & 4.1 & 5.5 & 4.0 & 2.2 & 3.1 \\
$95 \%$ & 6.6 & 11.9 & 7.3 & 3.3 & 5.1 & 4.4 & 4.8 & 7.8 & 2.9 & 3.4 \\
\hline
\end{tabular}

similar to the temperature pattern (Figure 4(a)), reflecting that precipitable water increases by increasing temperature. Projected changes in precipitation from the six simulations with the NorACIA-RCM are summarized in Table 7. The projected increase in mean annual precipitation up to year 2100 in the Longyearbyen area is $12 \%$ and for Bjørnøya $8 \%$. The precipitation is projected to increase during all seasons with the largest increase during spring. It should be noted that precipitation is quite scarce in the Longyearbyen area, implying that despite large relative increase, the absolute increase in seasonal precipitation may just be a few millimetres.

Benestad [34] carried out ESD for monthly precipitation totals for a selection of Norwegian Arctic sites, based on the most recent global climate model simulations. The results indicated that the secular variations in the actual observations were stronger than seen in the ESD results for the past. Also, the statistical links between the local (observed) and the large-scale (ERA40) precipitation was weak in general and of a very local nature [39]. In addition, some of the global models may not reproduce the regional precipitation characteristics in this region very well, thus introducing further errors and uncertainties in trying to identify the important spatial rainfall patterns in the AOGCMs. Consequently, the ESD-based projections for precipitation in the Spitsbergen area were considered to be rather uncertain, and the results are not included in this paper.

As an indicator for changes in extreme daily precipitation, Førland et al. [28] used the 5-percent exceedance value "95-percentile". For the MPIB2 simulation, they found that for 1-day rainfall, this $95 \%$ value at the end of this century over most of the Spitsbergen region may be exceeded 1-1.5 times more frequently than in present day climate. Also, changes in number of days with "heavy rainfall" (i.e., daily precipitation larger than $20 \mathrm{~mm}$ ) were studied [28]. In present climate, there may pass many years in the Svalbard region between each event which fulfils this definition of "heavy rainfall." Thus, even though the projected change in relative frequency is considerable, events with daily rainfall above $20 \mathrm{~mm}$ will be quite unusual ( $\sim 1$ day per year) also in the end of this century.

\section{Changes in Daily Temperatures in Longyearbyen up to Year 2050}

For impact and adaptation studies, climate development during the next $30-50$ years is more appropriate for planning purposes than changes up to the end of this century. As seen from Figure 5, the temperature increase up to year 2100 is close to linear. Estimated large-scale temperature changes for the next 40 years will thus be approximately $1 / 3$ of the values for the 110 year period in Table 6 . The vulnerable fauna and flora in the Svalbard region is exposed to extreme temperatures, and thus knowledge on daily temperatures above or below certain threshold values are important. To study changes in daily temperatures in the Svalbard Airport/ Longyearbyen area up to year 2050, the daily values from the RCM simulation MPI92a (Table 5) was adjusted as outlined in Section 3.1.

It is important to keep in mind that projections based on a single AOGCM and a single RCM only provide a rough idea of which direction the local climate may change [40,41]. However, Figure 5 shows that, except for the summer season, the warming up to 2021-2050 in the RCM simulations based on MPI92b is close to the median of the ESD ensemble. For the summer season, the MPI92b warming is in the upper part of the ensemble. Table 8 shows that the adjusted daily temperatures for the control period are in good accordance with the observed values during 1981-2010.

The annual $1 \%$ values (Table 8 ) illustrate that on average there are 3-4 days per year when the daily mean temperature drops below $-28^{\circ} \mathrm{C}$ or exceeds $9.5^{\circ} \mathrm{C}$ in present climate. During the $2021-2050$ period, the $1 \%$ value is $-23^{\circ} \mathrm{C}$ while the $99 \%$ value is $11^{\circ} \mathrm{C}$. For the summer season, the projected $1 \%$ value will be well above zero, and the temperature threshold exceeded on average just once a year will be around 
TABle 7: Changes in 5-, 50-, and 95-percentile precipitation totals (\%) from 1961-90 to 2071-2100 for Svalbard Airport and Bjørnøya. The projections are based on RCM simulations.

\begin{tabular}{lcccccccccc}
\hline \multirow{2}{*}{ Percentile } & \multicolumn{4}{c}{ Svalbard Airport/Longyearbyen } & \multicolumn{4}{c}{ Bjørnøya } \\
& Annual & Winter & Spring & Summer & Autumn & Annual & Winter & Spring & Summer & Autumn \\
\hline $5 \%$ & 17 & -4 & 35 & -12 & 10 & 9 & 1 & 40 & 0 & 12 \\
$50 \%$ & 12 & 4 & 28 & 11 & 21 & 8 & 4 & 17 & 8 & 5 \\
$95 \%$ & 15 & 6 & 21 & 9 & 4 & 7 & -2 & 20 & 3 & 1 \\
\hline
\end{tabular}

$+12^{\circ} \mathrm{C}$. While in the present climate there is on average one winter day every year with daily mean temperature lower than $-31^{\circ} \mathrm{C}$, the projected value for $2021-2050$ is $-25^{\circ} \mathrm{C}$.

In present climate, the Svalbard Airport/Longyearbyen area experiences around 240 days per year with daily mean temperature below zero (Table 9). During 2021-2050, the number of days per year with mean temperature below zero will be reduced to around 200 according the projection based on MPI92b. Days with very low mean temperature $\left(<-20^{\circ} \mathrm{C}\right)$ is projected by MPI92b to decrease from around 30 in present climate to around 10 during 2021-2050. For the Nordic region, the thermal growing season is often defined as the time of the year when the daily mean temperature exceeds $+5^{\circ} \mathrm{C}$ [42]. Table 9 indicates that number of thermal growing days will increase from around 50 in present climate to around 75 in the 2021-2050 period.

\section{Conclusions}

(i) The large-scale warming in the Arctic during the latest decades is recognized also at the measuring sites in the Svalbard region. During the latest two decades, the annual temperature at the different stations in the region has increased by $1.0-1.2^{\circ} \mathrm{C}$ per decade. The winter warming has been quite dramatic, with an increase of $2-3^{\circ} \mathrm{C}$ per decade at all stations. During the 1966-1988 and 1989-2011 periods, there is a positive linear trend for all seasons at all stations. However, during 1943-1965, there was a rather strong winter cooling $\left(0.9-1.8^{\circ} \mathrm{C}\right.$ per decade) at all stations, leading also to a negative trend in the annual temperatures.

(ii) Results from several downscalings by both dynamical (regional climate models) and empirical-statistical techniques project a substantial future warming in the Svalbard region. In general, there is good accordance between the results from the two different downscaling techniques. For the Svalbard Airport/Longyearbyen area, the projected warming from $1961-90$ to $2071-2100$ equals $0.6^{\circ} \mathrm{C}$ per decade for annual temperatures and $0.9^{\circ} \mathrm{C}$ per decade for the winter season. This is very close to the values reported by Hanssen-Bauer [13], and a much higher warming rate than observed during the latest 100 years, where the linear temperature increase was ca. $0.25^{\circ} \mathrm{C}$ per decade both annually and for the winter season. Thus, the projections indicate a future rate in temperature increase three times stronger than in the observational series during 1912-2011. The strongest temperature increase is projected for areas where the sea-ice extent will be reduced.

(iii) Linear temperature trends from the empiricalstatistically downscaled CMIP3 runs forced with observed greenhouse gas emissions were compared with observed trends at Svalbard Airport 19122010. For all seasons, the observed trend falls within the $10-90 \%$ confidence interval, suggesting that the downscaled results do span the observations. It is however, evident that there is a large spread in modelled trends indicating that the downscaled CMIP3-ensemble contains some models with unrealistic results. It should, therefore, be stressed that large uncertainties are linked to projections of future climate development in the Svalbard region.

(iv) For daily temperatures, the adjusted values from one simulation with a regional climate model indicate that the lower threshold for daily temperatures experienced in average just 3-4 times per year (1\% value) will increase from $-28^{\circ} \mathrm{C}$ in present climate to around $-23^{\circ} \mathrm{C}$ for the period $2021-2050$. For the summer season, the projections indicate that days with mean temperature below zero will not occur anymore towards the mid of this century. Number of days per year with thermal conditions for growing (mean temperature above $+5^{\circ} \mathrm{C}$ ) will increase from 50 days in present climate to around 75 during 20212050.

(v) There are substantial measuring errors for precipitation in the harsh Arctic climate at Svalbard, and several relocations of rain gauges have further complicated the analyses of long-term precipitation trends. However, all the long series from the Svalbard region indicate an increase in annual precipitation. At Svalbard Airport, the annual measured precipitation has in average increased by $2 \%$ per decade, while the increase at Bjørnøya and Ny-Ålesund are 3-4\% per decade.

(vi) RCM simulations project an increase in annual precipitation up to year 2100 of a few percent southwest of Spitsbergen and more than $40 \%$ in north-eastern parts of the archipelago. The empirical-statistical projections for the region were hampered by weak correlations between local and large-scale precipitation, and because several of the global models did not reproduce the regional precipitation characteristics. 
TABle 8: Percentiles ( 1 and 99) of daily temperatures $\left({ }^{\circ} \mathrm{C}\right)$ at Svalbard Airport in present and future climate. Control and scenario values are based on postprocessed temperatures from MPI92a.

\begin{tabular}{|c|c|c|c|c|c|c|}
\hline & \multicolumn{3}{|c|}{$1 \%$} & \multicolumn{3}{|c|}{$99 \%$} \\
\hline & Obs & Control & Scenario & Obs & Control & Scenario \\
\hline & 1981-2010 & 1981-2010 & $2021-2050$ & $1981-2010$ & $1981-2010$ & $2021-2050$ \\
\hline Spring & -27.2 & -27.8 & -24.2 & 2.9 & 2.7 & 5.7 \\
\hline Summer & -1.7 & -0.8 & 0.9 & 11.3 & 10.8 & 12.2 \\
\hline Autumn & -19.8 & -21.2 & -16.5 & 7.0 & 6.5 & 7.5 \\
\hline Winter & -31.2 & -30.5 & -24.6 & 2.4 & 1.3 & 2.8 \\
\hline Year & -27.9 & -27.8 & -23.0 & 9.7 & 9.5 & 10.9 \\
\hline
\end{tabular}

TABle 9: Number of days per year with daily mean temperature $\left(T^{\circ} \mathrm{C}\right)$ below or above threshold values at Svalbard Airport. Control and scenario values are based on postprocessed temperatures from MPI92a.

\begin{tabular}{lccccccccc}
\hline & \multicolumn{3}{c}{ Winter } & & \multicolumn{3}{c}{ Summer } & \multicolumn{3}{c}{ Year } \\
& Obs & Control & Scenario & Obs & Control & Scenario & Obs & Control & Scenario \\
& $1981-2010$ & $1981-2010$ & $2021-2050$ & $1981-2010$ & $1981-2010$ & $2021-2050$ & $1981-2010$ & $1981-2010$ & $2021-2050$ \\
\hline$T<-20$ & 17.3 & 19.9 & 5.7 & 0 & 0 & 0 & 27.1 & 31.0 & 9.9 \\
$T<-10$ & 54.6 & 55.1 & 36.1 & 0 & 0 & 0 & 109.1 & 107.5 & 70.3 \\
$T<0$ & 86.1 & 86.2 & 80.1 & 3.6 & 5.0 & 0 & 234.9 & 239.4 & 202.5 \\
$T>5$ & 0.1 & 0 & 0,0 & 46.2 & 44.7 & 66.7 & 50.0 & 48.4 & 75.2 \\
$T>10$ & 0 & 0 & 0 & 2.8 & 2.8 & 7.9 & 2.9 & 2.8 & 8.0 \\
\hline
\end{tabular}

Consequently, the ESD-based projections for precipitation in the Spitsbergen area were considered to be rather uncertain, and the results are not included in this paper.

(vii) It should be noted that the downscaled scenarios presented here all depend on results from AOGCMs where sea ice representation is rather crude, even though it has improved somewhat lately [2]. The recent loss of sea ice may enhance the regional and local Arctic warming, not only by altering the energy budget, but also by leading to a modification of large-scale atmospheric circulation. The further climate development in the Arctic will thus probably be closely linked to the development of the sea ice conditions.

\section{Acknowledgments}

This study is part of a Norwegian (http://www.noracia.npolar.no/) followup of the Arctic Climate Impact Assessment (http://www.amap.no/acia/). Thanks to our colleagues Ketil Isaksen, Øyvind Nordli, and Hanna Szewczyk-Bartnicka for assistance with Figures 1, 2, and 3. The authors also thank the two anonymous reviewers for valuable comments and suggestions.

\section{References}

[1] ACIA, Arctic Climate Impact Assessment, Cambridge University Press, 2005, http://www.amap.no/acia/.

[2] IPCC, Climate Change 2007: The Physical Science Basis. Contribution of Working Group I to the Fourth Assessment Report of the Intergovernmental Panel on Climate Chan, Cambridge University Press, 2007, Edited by S. Solomon, D. Quin et al.

[3] G. H. Miller, R. B. Alley, J. Brigham-Grette et al., "Arctic amplification: can the past constrain the future?" Quaternary Science Reviews, vol. 29, no. 15-16, pp. 1779-1790, 2010.

[4] P. L. Langen and V. A. Alexeev, "Polar amplification as a preferred response in an idealized aquaplanet GCM," Climate Dynamics, vol. 29, no. 2-3, pp. 305-317, 2007.

[5] M. C. Serreze, A. P. Barrett, and J. J. Cassano, "Circulation and surface controls on the lower troposheric air temperature field of the Artic," Journal of Geophysical Research, vol. 116, Article ID D07104, 2011.

[6] SWIPA, "Snow, Water, Ice and Permafrost in the Arctic," 2011, http://www.amap.no/swipa/.

[7] G. A. Meehl, C. Covey, T. Delworth et al., "The WCRP CMIP3 multimodel dataset: a new era in climatic change research," Bulletin of the American Meteorological Society, vol. 88, no. 9, pp. 1383-1394, 2007.

[8] J. Räisänen, " $\mathrm{CO}_{2}$-induced changes in interannual temperature and precipitation variability in 19 CMIP2 experiments," Journal of Climate, vol. 15, no. 17, pp. 2395-2411, 2002.

[9] Ø. Nordli, "The Svalbard airport temperature series," Bulletin of Geography-physical geography series, no.3/2010:5-26, 2010.

[10] E. J. Førland, I. Hanssen-Bauer, and Ø. Nordli, "Climate statistics and long-term series of temperature and precipitation at Svalbard and Jan Mayen," DNMI-Report 21/97, Norwegian Meteorological Institute, Oslo, Norway, 1997.

[11] Ø. Nordli, I. Hanssen-Bauer, and E. J. Førland, "Homogeneity analyses of temperature and precipitation series from Svalbard and Jan Mayen," DNMI-Report 16/96, Norwegian Meteorological Institute, Oslo, Norway, 1996.

[12] WMO, "Calculation of monthly 30-year standard normals," WMO-TD 341, World Meteorological Organisation, Geneva, Switzerland, 1989. 
[13] I. Hanssen-Bauer, "Temperature and precipitation in Svalbard 1912-2050: measurements and scenarios," Polar Record, vol. 38, no. 206, pp. 225-232, 2002.

[14] I. V. Polyakov, R. V. Bekryaev, G. V. Alekseev et al., "Variability and trends of air temperature and pressure in the maritime Arctic, 1875-2000," Journal of Climate, vol. 16, no. 12, pp. 2067-2077, 2003.

[15] I. Hanssen-Bauer and E. J. Førland, "Long-term trends in precipitation and temperature in the Norwegian Arctic: can they be explained by changes in atmospheric circulation patterns?" Climate Research, vol. 10, no. 2, pp. 143-153, 1998.

[16] I. G. Rigor, R. L. Colony, and S. Martin, "Variations in surface air temperature observations in the Arctic, 1979-97," Journal of Climate, vol. 13, no. 5, pp. 896-914, 2000.

[17] J. E. Overland and M. Wang, "Large-scale atmospheric circulation changes are associated with the recent loss of Arctic sea ice," Tellus A, vol. 62, no. 1, pp. 1-9, 2010.

[18] J., Overland, M. Wang, and J. Walsh, "Atmosphere," 2011, http://www.arctic.noaa.gov/reportcard/atmosphere.html.

[19] R. E. Benestad, "What can present climate models tell us about climate change?" Climatic Change, vol. 59, no. 3, pp. 311-331, 2003.

[20] L. Bengtsson, V. A. Semenov, and O. M. Johannessen, "The early twentieth-century warming in the arctic-a possible mechanism," Journal of Climate, vol. 17, no. 20, pp. 40454057, 2004.

[21] R. Sneyers, "On statistical analysis of series of observations," WMO Technical Note 143, Geneva, Switzerland, 1990.

[22] E. J. Førland and I. Hanssen-Bauer, "Increased precipitation in the Norwegian Arctic: true or false?" Climatic Change, vol. 46, no. 4, pp. 485-509, 2000.

[23] A. Sorteberg, T. Furevik, H. Drange, and N. G. Kvamstø, "Effects of simulated natural variability on Arctic temperature projections," Geophysical Research Letters, vol. 32, no. 18, Article ID L18708, 4 pages, 2005.

[24] R. E. Benestad, "On latitudinal profiles of zonal means," Geophysical Research Letters, vol. 32, no. 19, Article ID L19713, 4 pages, 2005.

[25] J. E. Walsh, W. L. Chapman, V. Romanovsky, J. H. Christensen, and M. Stendel, "Global climate model performance over Alaska and Greenland," Journal of Climate, vol. 21, no. 23, pp. 6156-6174, 2008.

[26] J. E. Haugen and T. Iversen, "Response in extremes of daily precipitation and wind from a downscaled multi-model ensemble of anthropogenic global climate change scenarios," Tellus A, vol. 60, no. 3, pp. 411-426, 2008.

[27] M. Stendel, J. H. Christensen, and D. Petersen, "Arctic climate and climate change with a focus on greenland," Advances in Ecological Research, vol. 40, pp. 13-43, 2008.

[28] E. J. Førland, R. E. Benestad, F. Flatøy et al., "Climate development in North Norway and the Svalbard region during 1900-2100," Norwegian Polar Institute Report 128, 2009.

[29] S. Uppala, P. W. Kållberg, A. J. Simmons et al., "The ERA40 re-analysis," Quarterly Journal of the Royal Meteorological Society, vol. 131, no. 612, pp. 2961-3012, 2005.

[30] T. Engen-Skaugen, "Refinement of dynamically downscaled precipitation and temperature scenarios," Climatic Change, vol. 84, no. 3-4, pp. 365-382, 2007.

[31] F. Giorgi and B. Hewitson, "Regional climate informationevaluation and projections," in Climate Change 2001: the Scientific Basis. Contribution of Working Group I to the Third Assessment Report of the Intergovernmental Panel on Climate Change, J. T. Houghton, Y. Ding, D. J. Griggs et al., Eds., pp. 583-638, Cambridge University Press, Cambridge, UK, 2001.
[32] I. Hanssen-Bauer, C. Achberger, R. E. Benestad, D. Chen, and E. J. Førland, "Statistical downscaling of climate scenarios over Scandinavia," Climate Research, vol. 29, no. 3, pp. 255-268, 2005.

[33] R. E. Benestad, "A new global set of downscaled temperature scenarios," Journal of Climate, vol. 24, no. 8, pp. 2080-2098, 2011.

[34] R. E. Benestad, "Empirical-Statistical downscaled Arctic temperature and precipitation series," Met.no Report 10/2008 Climate, 2008.

[35] R. E. Benestad, "Extension of the NorACIA and EALAT downscaling," Met.no Note 21, 2010.

[36] E. J. Førland, R. E. Benestad, I. Hanssen-Bauer, and J. E. Haugen, Future Climate Development in the NorACIARegion. Combined Results from Simulations with Different Climate Models, Brief Report Series, no. 023, Norwegian Polar Institute, 2011, (In Norwegian).

[37] SRES, IPCC Special Report on Emissions Scenarios, Cambridge University Press, Cambridge, UK, 2000.

[38] P. D. Jones, "The early twentieth century Arctic high-fact or fiction?" Climate Dynamics, vol. 1, no. 2, pp. 63-75, 1987.

[39] R. E. Benestad, I. Hanssen-Bauer, and E. J. Førland, "An evaluation of statistical models for downscaling precipitation and their ability to capture long-term trends," International Journal of Climatology, vol. 27, no. 5, pp. 649-665, 2007.

[40] N. Oreskes, D. A. Stainforth, and L. A. Smith, "Adaptation to global warming: do climate models tell us what we need to know?" Philosophy of Science, vol. 77, no. 5, pp. 1012-1028, 2010.

[41] T. Palmer, "A CERN for climate change," Physics World, vol. 24, no. 14-15, 2011.

[42] E. J. Førland, T. E. Skaugen, R. E. Benestad, I. Hanssen-Bauer, and O. E. Tveito, "Variations in thermal growing, heating, and freezing indices in the Nordic Arctic, 1900-2050," Arctic, Antarctic, and Alpine Research, vol. 36, no. 3, pp. 347-356, 2004. 

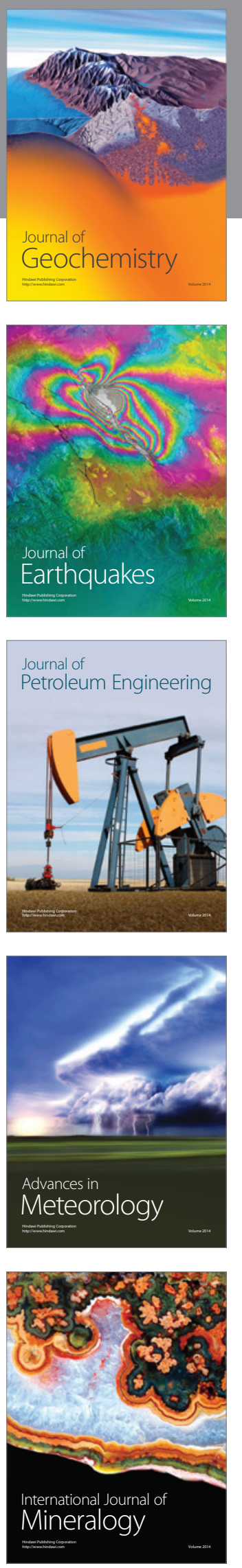
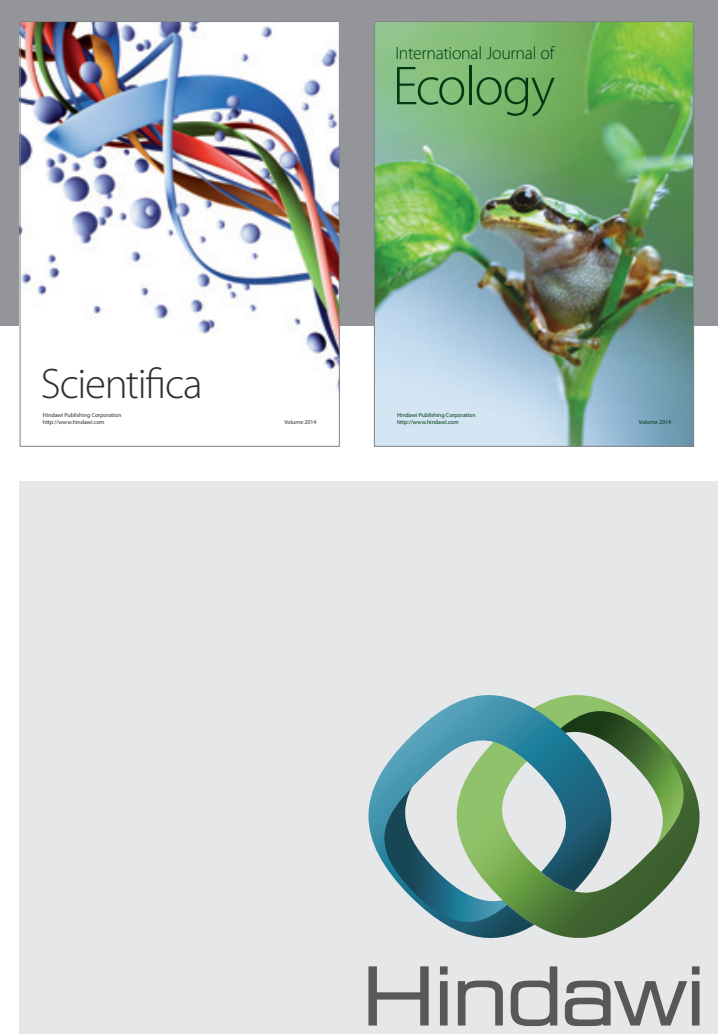

Submit your manuscripts at http://www.hindawi.com
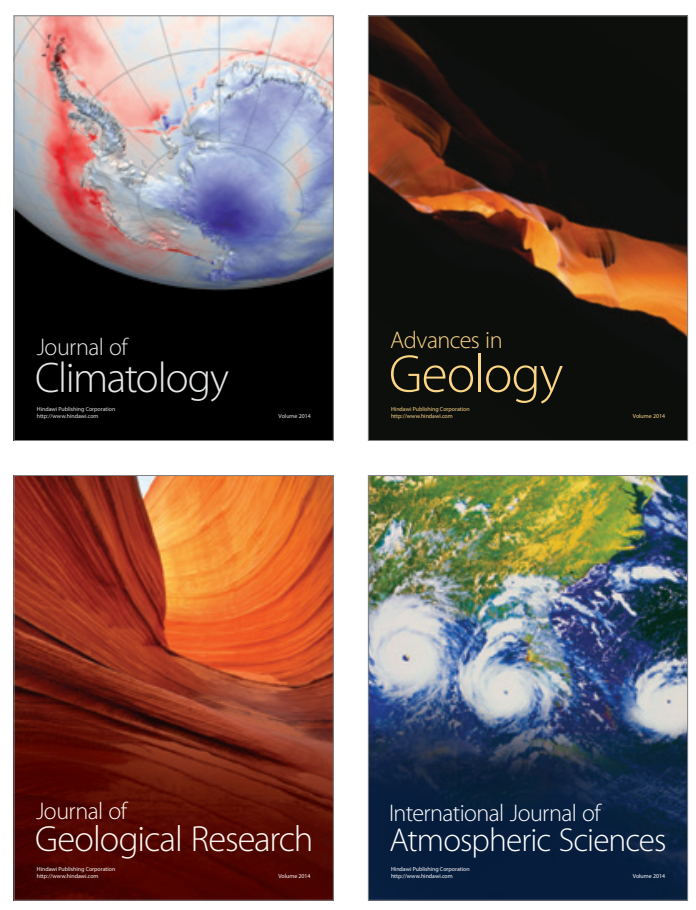
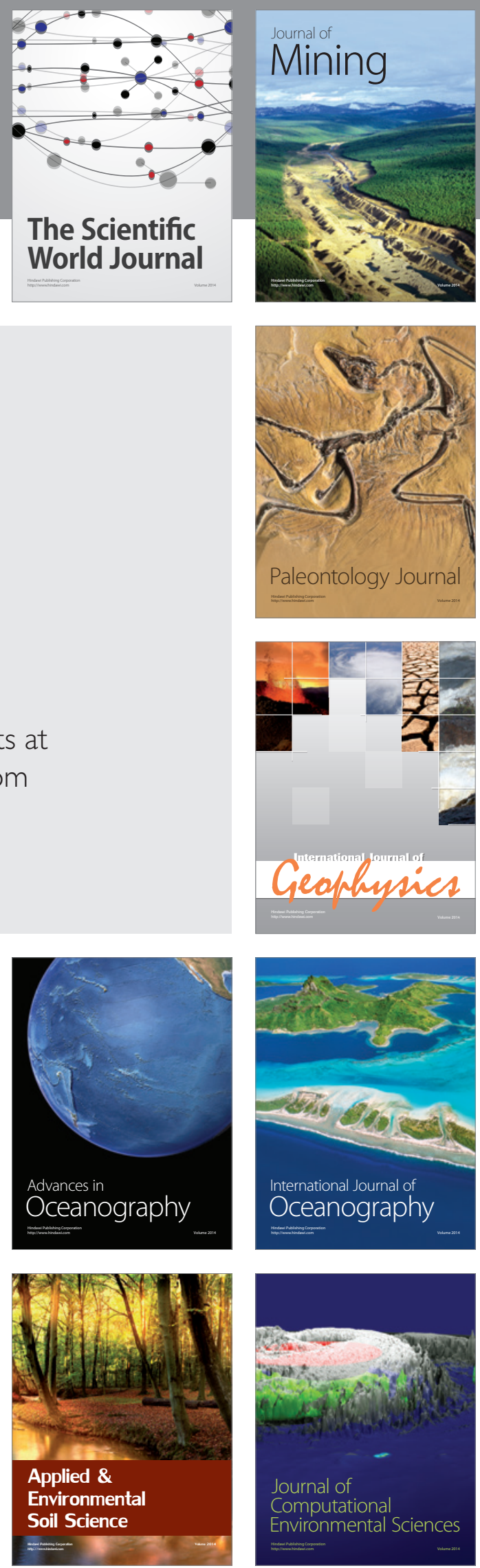